\title{
Ecological risks of polycyclic musk in soils irrigated with reclaimed municipal wastewater
}

\author{
Meie Wang ${ }^{\mathrm{a}}$, Chi Peng ${ }^{\mathrm{a}}$, Weiping Chen ${ }^{\mathrm{a}, *}$, Bernd Markert ${ }^{\mathrm{b}}$ \\ a State Key Laboratory of Urban and Regional Ecology, Research Centre for Eco-environmental Sciences, Chinese Academy of Sciences, Beijing, 100085, China \\ ${ }^{\mathrm{b}}$ Environmental Institute of Scientific Networks, Fliederweg 17, 49733 Haren/Erika, Germany
}

\section{A R T I C L E I N F O}

\section{Article history:}

Received 16 April 2013

Received in revised form

24 July 2013

Accepted 29 July 2013

Available online 23 August 2013

\section{Keywords:}

HYDRUS-1D, risk assessment

Predicted no effect concentration (PNEC)

Risk characterization ratio (RCR)

HHCB $(1,3,4,6,7,8$-hexahydro-4,6,6,7,8-

hexamethylcyclopenta-c-2-benzopyrane)

AHTN (7-acetyl-1,1,3,4,4,6-hexamethyl-

1,2,3,4-tetrahydronaphthalene)

\begin{abstract}
A B S T R A C T
HHCB (1,3,4,6,7,8-hexahydro-4,6,6,7,8-hexamethylcyclopenta-c-2-benzopyrane) and AHTN (7-acetyl1,1,3,4,4,6-hexamethyl-1,2,3,4-tetrahydronaphthalene) are found in reclaimed municipal wastewater. They may accumulate in soils receiving long-term application of reclaimed water thus adversely impact the soil biota. We evaluated the extent of their accumulation in receiving soils using HYDRUS-1D based on reclaimed municipal wastewater irrigation data at a public park in Beijing. The potential for ecological harms were assessed according to tested and reported outcomes of acute toxicity tests using wheat (Triticum aetivum L), earthworm (Eisenia fetida) and springtail (Bourletiella hortensis) as target organisms. Results of comparison among $\mathrm{EC}_{50}$ values from wheat, earthworm and springtail showed the $\mathrm{EC}_{50}$ value for root elongation inhibition of wheat germination was the least. Based on the least $\mathrm{EC}_{50}$, predicted no effect concentration in soils were 290 and $320 \mathrm{ng} / \mathrm{g}$ for HHCB and ATHN, respectively. Comparable results from simulation to experimental and field investigating date validated the using of HYDRUS-1D in the work. Results of risk prediction showed it would take 243 and 666 years for HHCB and AHTN accumulated in soils at current irrigation practice to reach the levels for the resulting risk characterization ratios $(R C R s)$ to cause potential ecosystem harms.
\end{abstract}

(c) 2013 Elsevier Inc. All rights reserved.

\section{Introduction}

Synthetic musk, fragrances manufactured to emulate scents of deer musk, is widely used in cosmetics, detergents, and personal care products. In natural settings, HHCB (1,3,4,6,7,8-hexahydro-4,6,6,7, 8-hexamethylcyclopenta-c-2-benzopyrane) and AHTN (7-acetyl-1, 1,3,4,4,6-hexamethyl-1,2,3,4-tetrahydronaphthalene) are by far the most frequently found compounds in this class of aromachemicals and are present in comparatively the highest concentrations (Hu et al., 2012; Zhou et al., 2009; Zhang et al., 2008; Zeng et al., 2005; Butte, 2004; Fromme et al., 2001). Soils are repositories for fugitive HHCB and AHTN (Litz et al., 2007; Müller et al., 2006; Yang and Metcalfe, 2006). And atmospheric deposition, waste disposal and reclaimed wastewater irrigation are primary contributing sources. Both compounds may be present in cropland soils that received municipal sewage sludge applications and HHCB may remain detectable in receiving soils for 6 months and longer (Yang and Metcalfe, 2006). Their pervasive presence and transports in terrestrial and aquatic environments are potential eco-toxicity risks.

\footnotetext{
* Corresponding author.

E-mail address: wpchen@rcees.ac.cn (W. Chen).
}

HHCB and AHTN were found to accumulate in the aquatic ecosystems (Rüdel et al. 2006). Organisms at the lower tropic levels exhibited greater sensitivities to the chemicals than those higher up in the ecological echelon (Nakata, 2005). The consequences of their presences in terms of bioaccumulation and ecosystem health in soil ecosystems however were ambiguous. Balk and Ford (1999b) reported NOECs of 105 (AHTN) and $45 \mathrm{mg} / \mathrm{kg}$ (HHCB) with earthworm (E. fetida) and of $45 \mathrm{mg} / \mathrm{kg}$ for both chemicals with springtail ( $H$. Bourletiella) by studied on mortality, reproduction, growth, and food consumption. Effects of HHCB and AHTN on biochemical and transcriptional changes of antioxidant enzymes superoxide dismutase (SOD) and catalase (CAT) and stress-response gene Hsp70 using acute contact toxicity tests on wheat and earthworm have been reported (Chen et al., 2011, 2010a, 2010b; Liu et al., 2011; An et al., 2009). All of their results so far suggested that HHCB and AHTN exhibit significant ecotoxicities on terrestrial biota at least at dozens of milligram per kilogram (liter) level. However, they did not calculate the doseresponse relationship for those biochemical parameters.

Beijing, due to a shortage of water resources, strongly advocated water reuses and employed the reclaimed wastewater to irrigate vegetative covers of many public parks. During the course of wastewater reclamation, the HHCB and AHTN removals are not complete, generally ranging from $41.7 \%$ to $70.1 \%$ and $25.5 \%$ to $68.8 \%$, respectively in Beijing (Zhou et al., 2009), and $72 \%$ to $98 \%$ in 
USA (Horri et al., 2007). The concentrations of HHCB and AHTN in reclaimed wastewater effluents varied from 157 to $3730 \mathrm{ng} / \mathrm{L}$ and 42 to $807 \mathrm{ng} / \mathrm{L}$, respectively in USA and European, and 493 to 1250 and 48 to $286 \mathrm{ng} / \mathrm{L}$ in Beijing, China, respectively (Reiner et al., 2007; Zhou et al., 2009). The reclaimed wastewater irrigated soils of public parks in Beijing might be reservoirs for the fugitive HHCB and AHTN. The compounds are strongly adsorbed and are resistant to degradation in the soils (Müller et al., 2006). As a result, they may accumulate in soils with long-term repeatedly inputs. Litz et al. (2007) reported that HHCB and AHTN did not readily decompose in soils with estimated degradation half life in soil and sewage sludge mixtures to reach 1-1.5 and 2-24 years, respectively. Difrancesco et al. (2004) found that HHCB and AHTN remained present in sludge amended soils three months after the applications and AHTN was still detectable in the sludge amended soils 12 months following the application. Balk and Ford (1999a) based on the degradation characteristics of HHCB and AHTN in four soils recommend that European Union System for Evaluation of Substances adopts 6 months as the degradation half-life of HHCB and AHTN present in soils (EUSES, 1997). The potential ecological risks associated with the reclaimed wastewater irrigation should be examined.

The objective of this study is to assess potential long-term ecorisks of HHCB and AHTN in urban soils that have been irrigated with reclaimed wastewater. Terrestrial organisms, wheat (Triticum aetivum $L$ ), earthworm (Eisenia fetida), and springtail (F. candida) are selected as the target organisms in the assessment due to the sufficiency of toxicological data about those three terrestrial species and their universality in soil environment. Long-term accumulation of HHCB and AHTN in soil is simulated using HYDRUS-1D, a water and solute fate and transport software package (Simunek and Van Genuchten, 2008).

\section{Materials and methods}

\subsection{Study site and determination of $H H C B$ and $A H T N$}

In order to evaluate the ecological risks of HHCB and AHTN input through reclaimed waste water irrigation two public parks in Beijing were selected as study cases. One of the parks is irrigated by reclaimed water while the other was irrigated by the public water. Those two parks are located nearby and have similarly general soil properties and surrounding environment. The vegetative covers in Longtanhu Park (39 52'31.08" N, 116 $26^{\prime} 1.68^{\prime \prime}$ E), off the south second ring road of Beijing, have been irrigated with reclaimed wastewater since 2002. Except for the reclaimed wastewater, there is no other known point source HHCB and AHTN emissions within a $5 \mathrm{~km}^{2}$ perimeter. In the nearby Taoranting Park $\left(39^{\circ} 52^{\prime} 15.24^{\prime \prime} \mathrm{N}, 116^{\circ} 22^{\prime}\right.$ $25.32^{\prime \prime} \mathrm{E}$ ), vegetations were irrigated by the public water supply. Surface $0-10 \mathrm{~cm}$ soils in these two locations were sampled in May, 2010 for HHCB and AHTN determinations.

The HHCB and AHTN in the freeze-dried soils were extracted by accelerated solvent extraction (ASE) using a Dionex ASE 300 equipped with a $34 \mathrm{ml}$ stainless steel extraction cell. Ten $g$ aliquot of the soil along with $10 \mathrm{~g}$ of pre-cleaned granular anhydrous diatomite was ground to fine powders in a glass mortar. The mixture was transferred into a $34 \mathrm{ml}$ ASE stainless steel sample cell and the sample was extracted with three successive 5 min cycles of equal volume n-hexane and dichloromethane mixture at pressure of $10.3 \mathrm{MPa}$ and temperature of $100{ }^{\circ} \mathrm{C}$. After passing through sodium sulfate, the extract was concentrated to $5 \mathrm{ml}$ and further cleaned up through a SPE column. Contents of HHCB and AHTN in irrigation water were also determined using approaches reported by Zhou et al., 2009.

Finished extracts were analyzed using an Agilent 6890 gas chromatography equipped with a 5975C mass selective detector. Oven temperature was programmed as follows: held for $1 \mathrm{~min}$ at $80^{\circ} \mathrm{C}$, increased at $10^{\circ} \mathrm{C} / \mathrm{min}-150{ }^{\circ} \mathrm{C}$ and held for $1 \mathrm{~min}$, increased at $2{ }^{\circ} \mathrm{C} / \mathrm{min}-170{ }^{\circ} \mathrm{C}$ and held for $1 \mathrm{~min}$, and at the end increased at $25^{\circ} \mathrm{C} / \mathrm{min}-300^{\circ} \mathrm{C}$ and held for $5 \mathrm{~min}$. The mass scan mode was Selective Ion Monitoring (SIM).

The analytical protocols were validated based on the analytes' recoveries, precision and repeatability, limit of quantification, linearity of calibration curve, and matrix influences. The limits of quantification were set at 0.19 and $0.295 \mathrm{ng} / \mathrm{g}$ for HHCB and AHTN, respectively namely 3.3 times of the respective limits of detection.The recoveries in soil were $70-116 \%$ for HHCB and $75-132 \%$ for AHTN. While the recoveries in water were $56-73 \%$ for $\mathrm{HHCB}$ and $64-78 \%$ for AHTN.

\subsection{Eco-toxicological assessments}

In order to calculate mathematically the dose-response relationship between HHCB and AHTN concentrations and responses of plant, acute eco-toxicological tests of HHCB and AHTN on wheat were assayed according to protocols outlined by Organization for Economic Cooperation and Development (OECD) Guidelines for Testing Chemicals (Test no. 208: Terrestrial Plant Test: Seedling Emergence and Seedling Growth Test). Wheat was screened as a model plant here for its sensitivity to pollutants and easiness for growing in lab (Wang and Zhou, 2006). The concentration gradient of HHCB and AHTN included seven levels soil concentration levels namely $0,50,100,150,200,250$, and $300 \mathrm{mg} / \mathrm{kg}$. For the assays, $100 \mathrm{~g}$ aliquots of HHCB- or AHTN-spiked soils were transferred to $100 \mathrm{~mm}$ (diameter) Petri dishes, ten wheat seeds were sowed in each dish, and the treated dishes were incubated in a biochemical culturing box at $25 \pm 2{ }^{\circ} \mathrm{C}$. Three parallel dishes were designed at each concentration levels. During the course of incubation, water content was maintained at $70 \%$ of the soil's water holding capacity. Testing parameters for the eco-toxic effects included germination rate, root and shoot elongations, SOD and POD activities, and soluble protein content in shoot and root.

Germination rate was determined at the time when shoot elongation in more than $60 \%$ of the germinated seeds in control had exceeded $3 \mathrm{~cm}$. Biochemical parameters i.e. SOD and POD activities were determined 7 days after the culturing. The length from seed to root tip and shoot tip was defined as root and shoot elongation respectively and were manually measured using a ruler.

All enzyme activity data are related to plant fresh weigh (FW) as kilo activity units per gram $(\mathrm{Ku} / \mathrm{g} \mathrm{FW})$. The activity of POD was determined using the guaiacol, $\mathrm{C}_{6} \mathrm{H}_{4}(\mathrm{OH})\left(\mathrm{OCH}_{3}\right)$, substrates as outlined in $\mathrm{Wu}$ and Von Tiedemann (2002). The activity of SOD was also determined according to Wu and Von Tiedemann (2002). One enzyme activity unit is defined as a $50 \%$ inhibition of the colorimetric reaction. The protein concentration in the supernatant part was determined by the dyebinding method according to Bradford (1976) and expressed as mg/g FW.

The dose-effect equations were obtained by the regression analysis between the HHCB and AHTN concentration and the inhibitory rate of each parameters compared to the contral. $\mathrm{EC}_{50}$ of $\mathrm{HHCB}$ and AHTN for wheat was estimated accordingly.

\subsection{HHCB and AHTN accumulation in soils}

Based on the low leaching capability reported by Litz et al. (2007), HHCB and AHTN accumulation in the $0-100 \mathrm{~cm}$ depth profile of soils irrigated with reclaimed wastewater was simulated using HYDRUS-1D, version. 4.14 (http://www.pc-pro gress.com/en/Default.aspx?hydrus-1d). For the simulation, the soil profile was divided into four layers namely $0-20 \mathrm{~cm}, 20-40 \mathrm{~cm}, 40-60 \mathrm{~cm}$ and $60-100 \mathrm{~cm}$ depths according to soil properties. HHCB and AHTN biodegradation was assume to take place only in the surface $20 \mathrm{~cm}$ layers, and the 6 month degradation half-life was adopt for both HHCB and AHTN according to European Union System for Evaluation of Substances (EUSES, 1997). The soil organic carbon distribution

Table 1

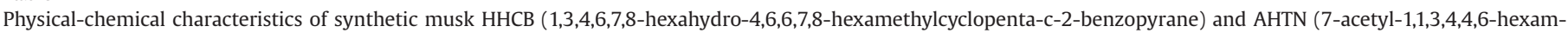
ethyl-1,2,3,4-tetrahydronaphthalene).

\begin{tabular}{|c|c|c|c|}
\hline Parameter & Soil depth $(\mathrm{cm})$ & НHCB & AHTN \\
\hline Diffusion coefficient, water ( $\left.\mathrm{cm}^{2} / \mathrm{d}\right)$ (Balk and Ford, 1999a) & - & 0.523 & 0.523 \\
\hline Diffusion coefficient, soil air ( $\left.\mathrm{cm}^{2} / \mathrm{d}\right)$ (Balk and Ford, 1999a) & - & 1421 & 1421 \\
\hline First order biodegradation rate constant $\left(\mathrm{d}^{-1}\right)$ (Balk and Ford, 1999a) & $0-20$ & 0.0039 & 0.0039 \\
\hline Henry's law constant $\left(\mathrm{Pa} \mathrm{m}^{3} / \mathrm{mol}\right)$ (Balk and Ford, 1999a) & - & 11.3 & 12.5 \\
\hline \multirow[t]{4}{*}{ Soil-solution distribution Coefficient, $K_{d}\left(\mathrm{~cm}^{3} / \mathrm{g}\right)\left(K_{d}=\left(K_{O C} \times \mathrm{OC} \%\right) / 100\right)$} & $0-20$ & 516 & 450 \\
\hline & $20-40$ & 411 & 358 \\
\hline & $40-60$ & 344 & 300 \\
\hline & $60-100$ & 201 & 175 \\
\hline
\end{tabular}


coefficients, $\log K_{O C}$, of HHCB and AHTN ranged from 3.44 to 4.86 and 3.58 to 4.80, respectively (Böhm and Düring, 2010; Litz et al., 2007; Ternes et al., 2004). For risk assessment purposes, the highest observed $\log K_{O C}$ value of each, 4.86 and 4.8 respectively, were used for in simulation (Balk and Ford, 1999a). $K_{d}$ values for each layers $(0-20 \mathrm{~cm}, 20-40 \mathrm{~cm}, 40-60 \mathrm{~cm}$ and $60-100 \mathrm{~cm})$ were calculated based on $K_{O C}$ and the organic carbon content of each layer. Rate constants including degradation, solid-solution phase distribution and diffusion in air and water for HHCB and AHTN were shown in Table 1. Table 2 summarizes the hydrological and physical parameters of the park soils used in the HYDRUS-1D simulation. The upper and lower boundary conditions for water flows were set as atmospheric boundaries of surface layer and free drainage, respectively. Irrigation frequency was three times per week at amounts equivalent to $120 \%$ of the cumulative in between irrigation evapotranspiration (ET). The ET was estimated as $60 \%$ of potential evapotranspiration $\left(\mathrm{ET}_{0}\right)$, that was calculated based on the Penman-Monteith equation using meteorological data of Beijing. The total irrigation water amount was set about $320 \mathrm{~mm}$ per year

\subsection{Predicted no effect concentration, $\mathrm{PNEC}_{\text {soil }}$}

Predicted no effect concentration of soils $\left(P N E C_{\text {soil }}\right)$ for HHCB and AHTN was calculated as follows (ECHA, 2008):

$P N E C_{\text {soil }}=\frac{K_{\text {soil-water }}}{R H O_{\text {soil }}\left(1+F C_{\text {water }}\right)} P N E C_{\text {water }} \times 1000$

where $P N E C_{\text {water }}$ is the chemical's predicted no effect concentration in water $(\mathrm{mg} / \mathrm{L}$ ) and they according to Balk (1999) are 0.0035 and $0.0068 \mathrm{mg} / \mathrm{L}$ for AHTN and HHCB, respectively, $K_{\text {soil-water }}$ is the chemical's soil-water distribution coefficient in the soil $(\mathrm{l} / \mathrm{kg}), R H O_{\text {soil }}$ is the bulk density of dry soils $\left(\mathrm{g} / \mathrm{cm}^{3}\right)$, and $F C_{\text {water }}$ is the field water capacity of the soil (\%).

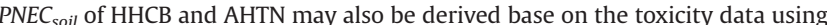
assessment factors. The results are normalized in terms of fractions of soil organic matter (ECHA, 2008):

$N O E C_{(\text {standard })}=N O E C_{(\exp )} \frac{\text { Fom }_{\text {soil(standard })}}{\text { Fom }_{\text {soil (exp) }}}$

$L C_{50(\text { standard })}=E C_{50(\exp )} \frac{\text { Fom }_{\text {soil(standard })}}{\text { Fom }_{\text {soil(exp) }}}$

$L E_{50(\text { standard })}=L E_{50(\exp )} \frac{\text { Fom }_{\text {soil(standard })}}{\text { Fom }_{\text {soil (exp) }}}$

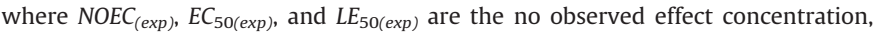
$L C_{50}$, or $L E_{50}$ obtained from experiments $(\mathrm{mg} / \mathrm{kg}), N O E C_{\text {(standard), }} L C_{50 \text { (standard) }}$ and $L E_{50 \text { (standard) }}$ are the no observed effect concentration, $L C_{50}$ and $L E_{50}$ of the standard

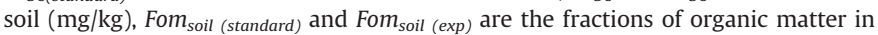
standard and experimental soils $(\mathrm{kg} / \mathrm{kg})$, respectively. Based on the ECHA (2008) protocol, the $P N E C_{\text {soil }}$ is obtained by multiplying the lowest toxicity concentration among the three i.e. $N O E C_{\text {(standard), }} L E_{50 \text { (standard), and } C_{50 \text { (standard) }} \text { by an assessment }}$ factor of 1000 . The lowest $P N E C_{\text {soil }}$ obtained was used in risk characterization.

\section{Results and discussion}

\subsection{Acute toxicity of $H H C B$ and AHTN to wheat}

The HHCB and AHTN did not appear to be toxic to wheat plants. The cause effect analyses showed that $E C_{50}$, the half maximal effective concentration, of HHCB and AHTN in the soils we tested varied from 85 to 2444 and 187 to $4322 \mathrm{mg} / \mathrm{kg}$, respectively

Table 2

Hydrodynamic characteristics of reclaimed wastewater irrigated soil employed in fate and transport simulations of HHCB and ATHN using HYDRUS-1D.

\begin{tabular}{clllllll}
\hline $\begin{array}{l}\text { Soil layer } \\
(\mathrm{cm})\end{array}$ & $\begin{array}{l}\theta_{r} \\
\left(\mathrm{~cm}^{3} / \mathrm{cm}^{3}\right)\end{array}$ & $\begin{array}{l}\theta_{s} \\
\left(\mathrm{~cm}^{3} / \mathrm{cm}^{3}\right)\end{array}$ & $\begin{array}{l}K_{s} \\
\left(\mathrm{~cm}^{3} / \mathrm{h}\right)\end{array}$ & $\begin{array}{l}a \\
\left(1 / \mathrm{cm}^{3}\right)\end{array}$ & $n$ & $\begin{array}{l}\rho \\
\left(\mathrm{g} / \mathrm{cm}^{3}\right)\end{array}$ & $\begin{array}{l}\text { OC } \\
(\%)\end{array}$ \\
\hline $0-20$ & 0.061 & 0.43 & 35.5 & 0.01 & 1.53 & 1.61 & 0.713 \\
$20-40$ & 0.071 & 0.47 & 35.5 & 0.02 & 1.55 & 1.52 & 0.568 \\
$40-60$ & 0.053 & 0.42 & 35.5 & 0.02 & 1.46 & 1.5 & 0.478 \\
$60-100$ & 0.051 & 0.41 & 35.5 & 0.01 & 1.43 & 1.46 & 0.278 \\
\hline
\end{tabular}

Notations for parameters: $\theta_{r}$ is residual soil water content, $\theta$ s is saturated soil water content, $K_{S}$ is saturated hydraulic conductivity, $\alpha$ is a parameter of soil water retention function, $n$ is a parameter of soil water retention function, $\rho$ is soil bulk density, and $O C$ is organic carbon content of soil. depending on the test parameters employed (Table 3). Reclaimed wastewater application can add a myriad of chemicals and potentially the synergistic effects of the multi-chemicals in irrigation water could lead to lower EC50s. However, the threshold levels shown here far exceeded what one might expect to accumulate in the reclaimed wastewater irrigated soils. In terms of the testing parameters, root elongation of wheat was the most sensitive at $E C_{50}=85$ and $185 \mathrm{mg} \mathrm{kg}^{-1}$ for HHCB and AHTN, respectively. It was followed by shoot elongation and germination rate at $E C_{50}=126-209 \mathrm{mg} / \mathrm{kg}$ and $438-750 \mathrm{mg} / \mathrm{kg}$ for HHCB and AHTN, respectively. At the cellular levels, wheat plants appeared to tolerate even higher HHCB and AHTN concentrations in the soils. The antioxidant activities of SOD and POD enzymes withstood $E C_{50}=358-2444$ and $343-3400 \mathrm{mg} / \mathrm{kg}$, for HHCB and AHTN, respectively. It appeared that at the concentration levels expected in soils HHCB and AHTN exhibit little acute toxicity.

\subsection{Predicted no effect concentration of soil $\left(P N E C_{\text {soil }}\right)$}

The $E C_{50}$ for acute toxicity of wheat was normalized in terms of the OECD standard soil according to Eq. (2) and adjusted for the uncertainties due to the short term acute toxicity tests by dividing by an assessment factor of 1000 to estimate the no observed effect concentration. In this manner, the experimental data became comparable and might be pooled with data of Balk and Ford (1999), see Table 4. The $P N E C_{\text {soil }}$ would be calculated from the lowest $E C_{50}$ of the pooled data set. The lowest $P N E C_{\text {soil }}$ of HHCB and ATHN were 0.29 and $0.32 \mathrm{mg} / \mathrm{kg}$, respectively.

Balk and Ford (1999b) provided the PNEC water of HHCB and AHTN from which the $P N E C_{\text {soil }}$ might be estimated through Eq. (1), resulting in $P N E C_{\text {soil }}=3.75$ and $1.68 \mathrm{mg} / \mathrm{kg}$ for $\mathrm{HHCB}$ and $\mathrm{AHTN}$, respectively. According to EU risk assessment protocols Technical Guidance Documents in support of Directive 96/67/EEC on risk assessment of new notified substances and Regulation (EC) no. $1488 / 94$ on risk assessment of existing substances (EC, 1996), when chemicals have the $\log K_{\text {ow }}$ more than 5 such as AHTN and $\mathrm{HHCB}$, the risk index $\left(P E C_{\text {soil }} / P N E C_{\text {soil }}\right)$ of earthworm or springtail derived from the $P N E C_{\text {soil }}$ based on the solid-solution equilibrium partitioning of Eq. (1) should be scaled down by a factor of 10 to account for the soil ingestion of the organisms. Thus, the $P N E C_{\text {soil }}$ derived from $P N E C_{\text {water }}$ through the solid solution phase equilibrium partitioning were down scaled to 0.38 and $0.17 \mathrm{mg} / \mathrm{kg}$ for HHCB and AHTN, respectively and were numerically comparable to those directly obtained from acute toxicity data appearing to indicate the aquatic and soil organisms exerted similar tolerances for HHCB and AHTN in the ecosystems.

Table 3

Acute toxicity end point $\left(\mathrm{EC}_{50}\right)$ of $\mathrm{HHCB}$ and $\mathrm{AHTN}$ on germinating wheat (Triticum acstivnm).

\begin{tabular}{|c|c|c|c|c|c|}
\hline \multirow{2}{*}{\multicolumn{2}{|c|}{ Parameter }} & \multicolumn{2}{|c|}{$\mathrm{EC}_{50}$ of $\mathrm{HHCB}(\mathrm{mg} / \mathrm{kg})$} & \multicolumn{2}{|c|}{$\mathrm{EC}_{50}$ of $\mathrm{AHTN}(\mathrm{mg} / \mathrm{kg})$} \\
\hline & & Determined & Normalized $^{\mathrm{a}}$ & Determined & Normalized $^{\mathrm{a}}$ \\
\hline \multicolumn{2}{|l|}{ Germination rate } & 679 & 438 & 1163 & 750 \\
\hline \multicolumn{2}{|l|}{ Shoot elongation } & 196 & 126 & 325 & 209 \\
\hline \multicolumn{2}{|l|}{ Root elongation } & 132 & 85 & 287 & 185 \\
\hline \multirow[t]{2}{*}{ Soluble content } & Leaf & 1043 & 670 & 6700 & 4322 \\
\hline & Root & 331 & 213 & 605 & 309 \\
\hline \multirow[t]{2}{*}{ SOD Inhibition } & Leaf & 555 & 358 & 1077 & 694 \\
\hline & Root & - & - & 627 & 404 \\
\hline \multirow[t]{2}{*}{ Inhibition POD } & Leaf & 3789 & 2444 & 532 & 343 \\
\hline & Root & 796 & 513 & 5271 & 3400 \\
\hline
\end{tabular}

a Determined result normalized according to protocols of Organization for Economic Cooperation and Development (OECD) Guidelines for Testing Chemicals 208 (EC 2006). 
Table 4

No toxic effect HHCB and AHTN concentrations for soil biota according to different test parameters. The lowest that of each chemical (highlighted in boldface) is designated as the predicted no effect concentration, $P N E C_{\text {soil }}$.

\begin{tabular}{|c|c|c|c|c|}
\hline \multirow{2}{*}{\multicolumn{2}{|c|}{ Test parameter }} & \multicolumn{2}{|c|}{$\begin{array}{l}\text { No toxic effect concentration } \\
\left(\mathrm{mg} \mathrm{kg}^{-1}\right)\end{array}$} & \multirow[t]{2}{*}{ Data resources } \\
\hline & & HHCB & AHTN & \\
\hline \multicolumn{2}{|l|}{ Germination rate } & 1.49 & 2.55 & Current work \\
\hline \multicolumn{2}{|l|}{ Shoot elongation } & 0.43 & 0.71 & Current work \\
\hline \multicolumn{2}{|l|}{ Root elongation } & 0.29 & 0.63 & Current work \\
\hline \multirow[t]{2}{*}{ Soluble content } & Leaf & 2.29 & 14.7 & Current work \\
\hline & Root & 0.73 & 1.33 & \\
\hline \multirow[t]{2}{*}{ Inhibition SOD } & Leaf & 1.22 & 2.36 & Current work \\
\hline & Root & Data absent & 1.38 & \\
\hline \multirow[t]{2}{*}{ Inhibition POD } & Leaf & 8.31 & 1.17 & Current work \\
\hline & Root & 1.75 & 11.6 & \\
\hline \multicolumn{2}{|l|}{ Earthworm } & 0.32 & 0.32 & Balk and Ford (1999) \\
\hline \multicolumn{2}{|l|}{ Springtail } & 0.32 & 0.32 & Balk and Ford (1999) \\
\hline
\end{tabular}

Table 5

HHCB and AHTN contents of reclaimed wastewater and soils irrigated with reclaimed wastewater, Beijing. The HHCB and AHTN contents of public water supply were below the limits of detection and were not tabulated.

\begin{tabular}{|c|c|c|c|c|}
\hline \multirow[t]{2}{*}{ Chemical } & \multicolumn{2}{|c|}{$\begin{array}{l}\text { Irrigated soils of current study } \\
\text { (ng/g) }\end{array}$} & \multicolumn{2}{|c|}{ Reclaimed wastewater (ng/l) } \\
\hline & Reclaimed water & Public water & Citywide range $^{a}$ & Current study \\
\hline HHCB & $1.33-2.55$ & $0.233-0.435$ & $492-2766$ & $200-251$ \\
\hline AHTN & $1.91-3.92$ & $0.330-0.659$ & $47-315$ & $65-130$ \\
\hline
\end{tabular}

a Zhou et al. (2009).

\subsection{Accumulation of HHCB and AHTN in soils}

The reclaimed water used for irrigation in Beijing contained 200-251 and 65-130 ng/L of HHCB and AHTN, respectively (Table 5). When the soils were irrigated with the public water supply of Beijing, HHCB and AHTN contents of the receiving soils were less than $1 \mathrm{ng} / \mathrm{g}$. In comparison, concentrations of HHCB and AHTN in soils irrigated with Beijing's reclaimed wastewater were $1.33-2.55$ and $1.91-3.92 \mathrm{ng} / \mathrm{g}$, respectively. While reclaimed wastewater irrigation has resulted in HHCB and AHTN accumulation in receiving soils, it nevertheless problematic to evaluate the extents of HHCB and AHTN accumulation as their concentrations in soils was barely above the limits of detection.

We employed HYDRUS-1D to assess consequences of HHCB and AHTN accumulation in soils receiving long-term applications of reclaimed municipal wastewater. Based on the HHCB and AHTN concentration ranges of reclaimed wastewater in Beijing (Table 5), the HHCB and AHTN concentrations of irrigation water, for the purpose of simulations, were fixed at 250 and $100 \mathrm{ng} / \mathrm{L}$, respectively.

Volatilization is a significant dissipating process for HHCB and AHTN during irrigating. As it shown in Table 6, the input amounts of HHCB and AHTN with volatilization process considered would be $5-6$ times lower than those without volatilization process considered. While the simulated mass balances of НHCB and AHTN in irrigated soils were separated into three components, namely storage in soils, microbial degradations and uptake by plants (Table 6).

It was reported that the compounds were readily adsorbed by the soil particles and did not readily leach down the soil depths (Litz et al., 2007), which is consistent with the results of HYDRUS1D simulation. It was suggested that after 8 years of reclaimed wastewater irrigation, the HHCB and AHTN were found in surface $8 \mathrm{~cm}$ of the soil profiles (data not shown), and following 40 years
Table 6

Results of mass balance simulation for HHCB and AHTN amounts in soils through reclaimed water irrigation with or without volatilization process.

\begin{tabular}{llllc}
\hline Time & Volatilization Process & Mass balance & $\begin{array}{l}\mathrm{HHCB} \\
\left(\mathrm{ng} / \mathrm{cm}^{2}\right)\end{array}$ & $\begin{array}{l}\text { AHTN } \\
\left(\mathrm{ng} / \mathrm{cm}^{2}\right)\end{array}$ \\
\hline \multirow{2}{*}{8 years } & \multirow{2}{*}{ Volatilization considered } & Input & 12.7 & 5.72 \\
& & Degradation & 0.032 & 0.012 \\
& & Uptake & 0.165 & 0.118 \\
& Residual & 12.5 & 5.59 \\
& \multirow{4}{*}{ No volatilization considered } & Input & 63.8 & 25.5 \\
& & Degradation & 0.122 & 0.043 \\
& & Uptake & 0.185 & 0.146 \\
& Residual & 62.8 & 25.3 \\
& \multirow{4}{*}{ Volatilization considered } & Input & 50.6 & 21.9 \\
& & Degradation & 0.498 & 0.186 \\
& Uptake & 1.87 & 1.46 \\
& \multirow{2}{*}{ No volatilization considered } & Residual & 48.2 & 20.3 \\
& & Input & 319 & 128 \\
& & Degradation & 3.00 & 1.04 \\
& Uptake & 2.15 & 1.80 \\
& & Residual & 314 & 125 \\
\hline
\end{tabular}

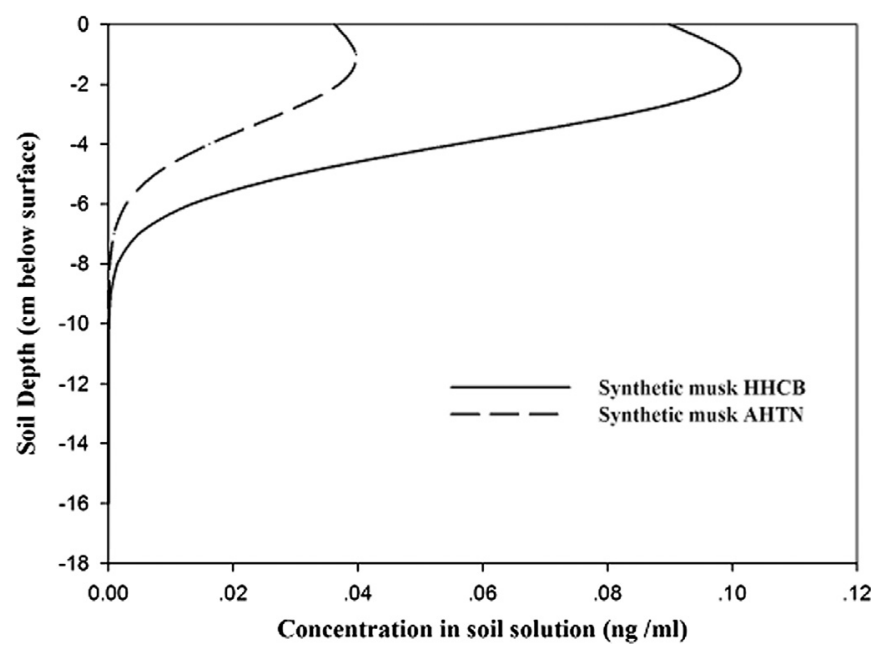

Fig. 1. Profile distribution of synthetic musk AHTN and HHCB in receiving soils after 40 years of reclaimed wastewater irrigation at Longtanhu Park, Beijing.

of continuing irrigation with reclaimed wastewater the HHCB and AHTN were found in surface $15 \mathrm{~cm}$ of the soil profiles (Fig. 1), mainly accumulated in the surface $10 \mathrm{~cm}$ soil profile.

Based on the simulated residual amount of HHCB and AHTN (Table 6), the estimated concentrations of those two musks in the surface $10 \mathrm{~cm}$ soil after 8 years of irrigation were 0.776 and $0.343 \mathrm{ng} / \mathrm{g}$ for HHCB and AHTN, respectively, with volatilization process considered, and 3.90 and $1.57 \mathrm{ng} / \mathrm{g}$ without volatilization process considered. Due to the uncertainty in estimating amounts of volatlization, the estimated concentrations with volatilization process might be considered as the lowest level and estimated concentrations without volatilization process be the highest level. The HHCB concentrations $(1.33-2.55 \mathrm{ng} / \mathrm{g})$ from field investigation were in the range of estimated $(0.776-3.90 \mathrm{ng} / \mathrm{g})$. While the estimated concentration of ANTH $(0.343-1.57 \mathrm{ng} / \mathrm{g})$ were obviously lower than those from field investigation (1.91-3.92) (Table 5). The inconsistency might be because the real biodegradation half-life for AHTN in our study soil was more than 6 month as recommonded by European Union System for Evaluation of Substances (EUSES, 1997). It was shown that biodegradation half-life for AHTN in soils amended with AHTN contained sludg was more than one year (Difrancesco et al., 2004). Or under real field condition, the 
A

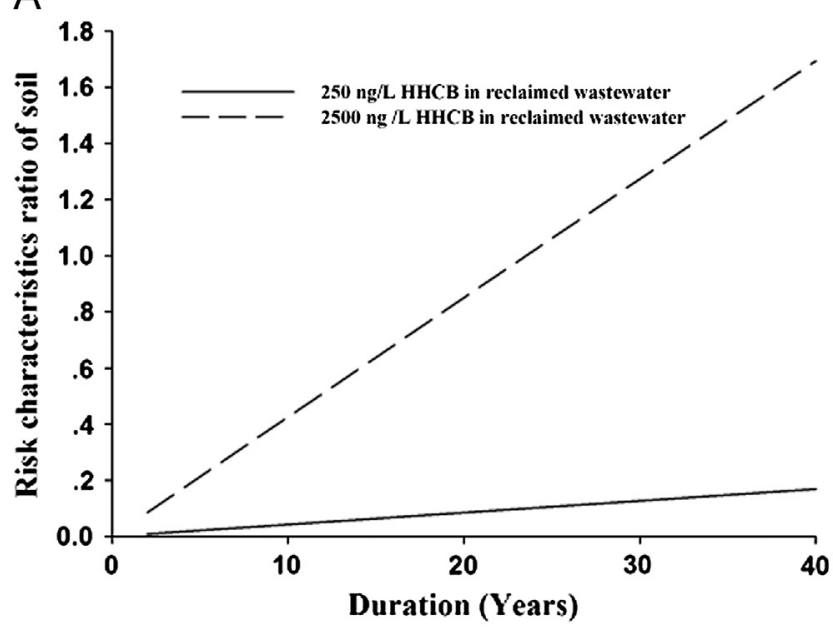

B

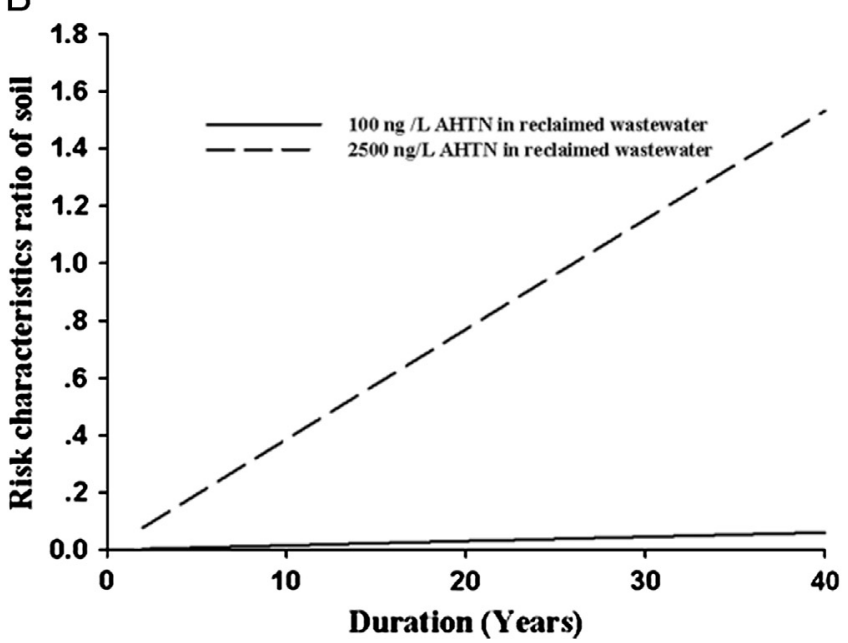

Fig. 2. Risk characterization ratios (RCRs) of synthetic musk accumulated in soils irrigated with reclaimed wastewater for 40 years, (a) HHCB and (b) AHTN.

background levels of HHCB and AHTN were not zero, while we assumed zero background leve in model simulation. Comparison of values from field investigation and model simulation for both of HHCB and AHTN suggested that volatilization processes were insiginificant when under real field conditions.

\subsection{Risk characterization}

The potential ecological harms of the HHCB and AHTN accumulating on the reclaimed wastewater irrigated soils may be evaluated based on the risk characterization ratio $(R C R)$ that is a quotient for comparing the exposure level i.e. the ambient concentration of the chemicals against their respective PNECS whose endpoints are specific for target organisms, mode of exposures, and temporal scales. If the resulting $R C R$ is less than unity, the ambient concentration is less than the PNEC and no harm would be expected. The severity of harm increases in proportion with the extent the resulting $R C R$ exceeds the unity.

The RCRs of HHCB and AHTN in soils irrigated with reclaimed wastewater might be estimated by the chemicals accumulated in soils without volatilization process considered (Table 6) and the $P N E C_{\text {soil }}$ summarized in Table 4. The HHCB and AHTN concentrations of the irrigation water are set to $2500 \mathrm{ng} / \mathrm{L}$ which is the highest concentration for HHCB and almost ten times for AHTN according to the investigation by Zhou et al. (2009), mimicking a worst case scenario. While $250 \mathrm{ng} / \mathrm{L}$ HHCB and $100 \mathrm{ng} / \mathrm{L}$ AHTN in the riigation water are set to simulate a normal case scenario (Table 5).

The RCRs of AHTN and HHCB increased linearly over 40 years of reclaimed wastewater irrigation (Fig. 2). Under the projected worst case scenario, it would take 24 and 26 years for the HHCB and AHTN concentrations to reach the levels that their respective $R C R s$ would exceed unity. Under the current practice, it would take 243 and 666 years of continued reclaimed wastewater irrigation for the HHCB and ATHN contents of receiving soils, respectively to reach the levels that their respective $R C R$ s would exceed unity and the cumulated compounds to become potentially harmful to soil biota such as earth worms and wheat plants.

\section{Conclusion}

Potential risks of ecosystem harms caused by HHCB and AHTN accumulating in soils receiving long-term reclaimed wastewater irrigations were assessed. The conclusions are as follows:

1. The HHCB and AHTN concentrations of reclaimed wastewater irrigated soils were significantly higher than comparable soils irrigated using the source tap water.

2. Based on short-term acute toxicity tests on wheat, the shoot and root elongation of germinating wheat plants were more sensitive to presence of HHCB and ATHN in soils than activities of the activities of SOD and POD enzymes. And results from reported references and this study showed that overall, the potential ecological harms caused by the presence of HHCB and ATHN in the soil did not appear to be significant.

3. Based on outcomes of fate and transport simulation using HYDRUS $1 \mathrm{D}$, the HHCB and ATHN inputs through reclaimed wastewater irrigation accumulated almost entirely in the surface soil layer, the downward transport through the soil profile, biodegradation, and plant uptake were considerably less significant. The simulated concentrations of HHCB and AHTN in $0-10 \mathrm{~cm}$ soil profile were 0.776 and $0.343 \mathrm{ng} / \mathrm{g}$, respectively, with volatilization process considered, and 3.90 and $1.57 \mathrm{ng} / \mathrm{g}$, respectively, without volatilization process considered. The modulated values were comparable to experimental and field investigated data, which means the valuable of the using of HYDRUS-1D in this work.

4. Under the current practice, it would take 243 and 666 years for HHCB and AHTN accumulated in soils receiving reclaimed wastewater irrigation to reach the levels for the resulting risk characterization ratios (RCRs) to cause potential ecosystem harms to soil biota such as germinating wheat plants and earthworms.

\section{Acknowledgments}

We gratefully acknowledged financial supports provided by the National Natural Science Foundation of China (Grant nos. 41030744 and 40930739) and the Special Foundation of State Key Laboratory of Urban and Regional Ecology (Grant no. SKLURE2008-1-4).

\section{References}

An, J., Zhou, Q., Sun, Y., Xu, Z., 2009. Ecotoxicological effects of typical personal care products on seed germination and seedling development of wheat (Triticum aetivum L.). Chemosphere 76, 1428-1434.

Balk, F., Ford, R., 1999a. Environmental risk assessment for the polycyclic musks AHTN and HHCB in the EU, I. Fate and exposure assessment. Toxicol. Lett. 11, 57-79.

Balk, F., Ford, R., 1999b. Environmental risk assessment for the polycyclic musks AHTN and HHCB in the EU, II. Effect assessment and risk characterization. Toxicol. Lett. 111, 81-94. 
Böhm, L., Düring, R., 2010. Partitioning of polycyclic musk compounds in soil and aquatic environment-experimental determination of $K_{D O C}$. J. Soil Sediment. 10 708-713.

Bradford, M.M., 1976. A rapid and sensitive method for the quantitation of microgram quantities of protein utilizing the principle of protein-dye binding. Anal. Biochem. 72, 248-254.

Butte, W., 2004. Synthetic musks in house dust. Rimkus, G.G. (Ed.), The Handbook of Environmental Chemistry. 3, Part X, pp. 105-121.

Chen, C., Zhou, Q., Bao, Y., Li, Y., Wang, P., 2010a. Ecotoxicological effects of polycyclic musks and cadmium on seed germination and seedling growth of wheat (Triticum aestivum). J. Environ. Sci. 22 (12), 1966-1973.

Chen, C., Zhou, Q., Zhang, C., Wang, Y., 2010b. Effects of soil polycyclic musk and cadmium on pollutant uptake and biochemical responses of wheat (Triticum aestivum). Arch. Environ. Contam. Tox. 59, 564-573.

Chen, C., Zhou, Q., Liu, S., Xiu, Z., 2011. Acute toxicity, biochemical and gene expression responses of the earthworm Eisenia fetida exposed to polycyclic muks. Chemosphere 83, 1147-1154.

Difrancesco, A., Chiu, P., Standley, L., Allen, H., Salvito, D., 2004. Dissipation of fragrance materials in sludge-amended soils. Environ. Sci. Technol. 38 (1), 194-201.

EC., 1996. Technical Guidance Documents in support of Directive 96/67/EEC on risk assessment of new notified substances and Regulation (EC) No. 1488/94 on risk assessment of exisiting substances (Parts I, II, III and IV). EC catalogue numbers CR-48-96-001, 002, 003, 004-EN-C, Office for Official Publications of the European Community, 2 Rue Mercier, L-2965 Luxembourg.

EC., 2006. OECD Guidelines for the Testing of Chemicals, Terrestrial Plant Test: Seedling Mergence and Seedling Growth Test. OECD/OCDE 208.

ECHA, 2008. 〈http:/cdmd.cnki.com.cn/Article/CDMD-82201-2009194248.htm〉.

Fromme, H., Otto, H., Pilz, K., 2001. Polycyclic musk fragrances in different environmental compartments in Berlin (Germany). Water Resour. 35 (1), 121-128.

Horri, Y., Reiner, J.L., Loganathan, B.G., Kumar, K.S., Sajwan, K., Kannan, K., 2007. Occurrence and fate of polycyclic musks in wastewater treatment plants in Kentucky and Georgia. Chemosphere 68, 2011-2020.

Hu, Z., Shi, Y., Niu, H., Cai, Y., 2012. Synthetic musk fragrances and heavy metals in snow samples of Beijing urban area, China. Atmos. Res. 104-105, 302-305.
Litz, N., Müller, J., Böhmer, W., 2007. Occurrence of polycyclic musks in sewage sludge and their behavior in soils and plants, Part2: Investigation of polycyclic musks in soils and plants. J. Soil Sediment. 7 (1), 36-44.

Liu, S., Zhou, Q., Wang, Y., 2011. Ecothoxicological responses of the earthworm Eisenia fetida exposed to soil contaminated with HHCB. Chemosphere 83, 1080-1086.

Müller, J., Böhmer, W., Litz, N., 2006. Occurrence of polycyclic musks in sewage sludge and their behavior in soils and plants, Part 1: Behavior of polycyclic musks in sewage sludge of different treatment plants in summer and winter. J. Soil Sediment. 6 (4), 231-235.

Nakata, H., 2005. Occurrence of synthetic musk fragrances in marine mammals and sharks from Japanese coastal waters. Environ. Sci. Technol. 39 (10), 3430-3434.

Reiner, J.L., Berset, J.D., Kannan, K., 2007. Mass flow of polycyclic musks in two wastewater treatment plants. Arch. Environ. Contam. Toxicol. 52, 451-457.

Simunek, J., Van Genuchten, M.T.h., 2008. Modeling nonequilibrium flow and transport processes using HYDRUS. Vadose Zone J. 7, 782-797.

Ternes, T., Herrmann, N., Matthias, B., Knacker, T., Siegrist, H., Joss, A., 2004. A rapid method to measure the solid-water distribution coefficient (Kd) for pharmaceuticals and musk fragrances in sewage sludge. Water Res. 38, 4075-4084.

Wang, M., Zhou, Q.X., 2006. Joint stress of chlorimuron-ethyl and cadmium on wheat Triticum aestivum at biochemical levels. Environ. Pollut. 144 (2), $572-580$.

Wu, X.Y., Von Tiedemann, A., 2002. Impact of fungicides on active oxygen species and antioxidant enzymes in spring barley (Hordeum vulgare L.) exposed to ozone. Environ. Pollut. 116, 37-47.

Yang, J., Metcalfe, C., 2006. Fate of synthetic musks in a domestic wastewater treatment plant and in an agricultural field amended with biosolids. Sci. Total Environ. 363, 149-165.

Zeng, X., Sheng, G., Xiong, Y., Fu, J., 2005. Determination of polycyclic musks in sewage sludge from Guangdong, China using GC-EI-MS. Chemosphere 60, 817-823.

Zhang, X., Yao, Y., Zeng, X., Qian, G., Guo, Y., 2008. Synthetic musks in the aquatic environment and personal care products in Shanghai, China. Chemosphere 72 , 1553-1558.

Zhou, H., Huang, X., Gao, M., Wang, X., Wen, X., 2009. Distribution and elimination of polycyclic musks in three sewage treatment plants of Beijing, China. J. Environ. Sci. 21, 561-567. 